\title{
Commentary: Management of late pulmonary regurgitation: Moving from certain palliation toward potential cure
}

\author{
Joseph B. Clark, MD
}

From the Division of Pediatric Cardiac Surgery, Department of Pediatrics, Penn State Children's Hospital, Hershey, Pa.

Disclosures: Author has nothing to disclose with regard to commercial support.

Received for publication July 16, 2019; accepted for publication July 17, 2019; available ahead of print Aug 21, 2019.

Address for reprints: Joseph B. Clark, MD, 500 University Dr, H085, Hershey, PA 17033 (E-mail: jclark7@ pennstatehealth.psu.edu).

J Thorac Cardiovasc Surg 2020;159:2395-6

$0022-5223 / \$ 36.00$

Copyright (c) 2019 by The American Association for Thoracic Surgery

https://doi.org/10.1016/j.jtcvs.2019.07.040

With this update and expansion of their previous work, Adamson and colleagues at Stanford have reported the largest experience of secondary pulmonary valve repair. ${ }^{1}$ Although this single-surgeon series is limited in size and follow-up, it offers encouraging findings that might influence the management of this population. Previously described in case reports, technique articles, and small series, secondary pulmonary valve repair (also known as recycling, restoration, or restitution) offers an "elegant solution" 2 to the management of late pulmonary insufficiency after previous treatment of right ventricular outflow tract disease. For patients with residual valve leaflets and favorable anatomy, secondary repair seeks to provide a living, durable valve at the pulmonary position.

This study offers specific tools to predict who might be a satisfactory candidate for valve repair. Intuitively, the technique is most successful when native leaflets remain adequate in number and size, and the more leaflet tissue present, the better. Consequently, at original surgery, to afford the opportunity for future leaflet growth and valve repair, surgeons should leave the native leaflets in situ with minimal harm. When the valve has an anterior commissure, this goal is easily achieved because the transannular incision can be carried through the commissure without violating the cusps.

Even with the contemporary drive toward valve-sparing repair of tetralogy of Fallot, freedom from late pulmonary regurgitation might not be as good as expected, with perhaps most patients experiencing significant late insufficiency. ${ }^{3,4}$ Thus, there might be an increasing number of valve-spared patients with progressive pulmonary regurgitation and preserved native leaflets who represent excellent candidates for secondary repair.

As transcatheter valve replacement has become increasingly prevalent, the opportunity to offer functional

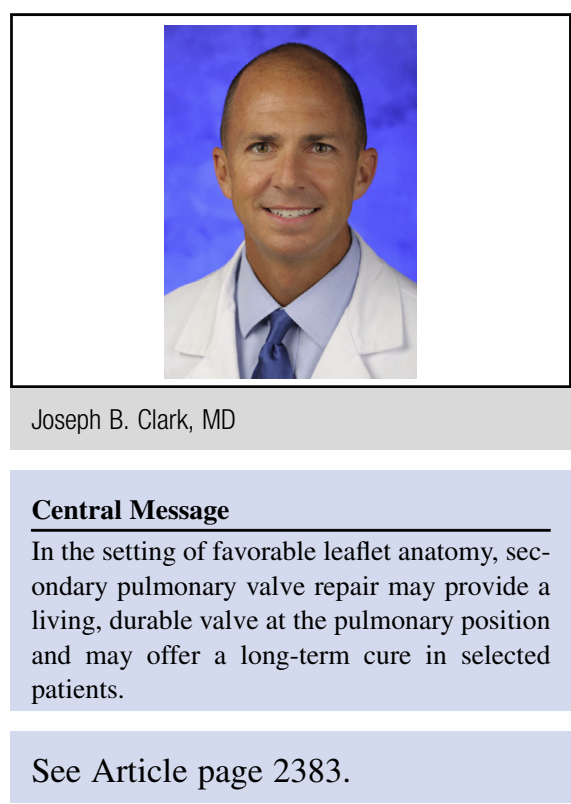

restoration of the native valve represents an important alternative technique. In the presence of good residual leaflets demonstrated using imaging, clinicians should thoughtfully weigh the options of transcatheter valve replacement versus surgical repair or replacement. In the former, the patient avoids sternotomy and cardiopulmonary bypass, but is committed to future valve replacements. In the latter, the door is open to native valve rehabilitation, which, with an optimal result, might provide a lifetime of satisfactory function.

Secondary valve repair in this series was associated with intermediate results similar to bioprosthetic valve replacement. Although the lifespan of pulmonary valve substitutes has been well-characterized, the late performance of the reconstructed native valve remains unclear, and larger studies with longer follow-up will be needed to determine the durability of repair techniques. By bringing attention to the equivalency of secondary pulmonary valve repair, and perhaps its superiority, the authors have encouraged us to look for native leaflet tissue on imaging and at surgery and consider repair in patients presenting for pulmonary valve intervention. Although current replacement options are relatively low-risk, reliable, and predictable, they remain palliative at best. Should further studies demonstrate that pulmonary valve repair can produce a long-term cure in 
selected patients, it should be considered a preferred strategy for provision of pulmonary valve competence.

\section{References}

1. Adamson GT, McElhinney DB, Lui G, Meadows AK, Rigdon J, Hanley FL, et al. Secondary repair of incompetent pulmonary valves after prior surgery or intervention: patient selection and outcomes. J Thorac Cardiovasc Surg. 2020; 159:2383-92.e2.
2. Prêtre R, Rosser B, Mueller C, Kretschmar O, Dave H. Recycling of the pulmonary valve: an elegant solution for secondary pulmonary regurgitation in patients with tetralogy of Fallot. Ann Thorac Surg. 2012;94:850-3.

3. Hofferberth SC, Nathan M, Marx GR, Lu M, Sleeper LA, Marshall AC, et al. Valve-sparing repair with intraoperative balloon dilation in tetralogy of Fallot: midterm results and therapeutic implications. J Thorac Cardiovasc Surg. 2018; 155:1163-73.

4. Hoashi T, Kagisaki K, Meng Y, Sakaguchi H, Kurosaki K, Shiraishi I, et al. Longterm outcomes after definitive repair for tetralogy of Fallot with preservation of the pulmonary valve annulus. J Thorac Cardiovasc Surg. 2014;148:802-9. 